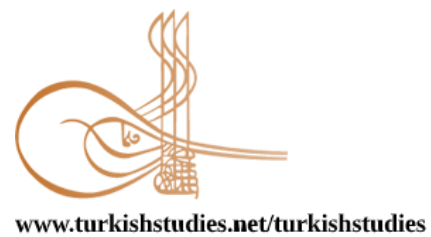

Turkish Studies

\title{
COVID-19 Pandemisi Sürecinde Fen Bilimleri Öğretmenlerinin Uzaktan Eğitime İlişkin Görüşleri"
}

\author{
Science Teachers' Views on Distance Education in the COVID-19 Pandemic Process
}

\author{
Büşra Bakioğlu** - Mustafa Çevik ${ }^{* * *}$
}

\begin{abstract}
Recently, the COVID-19 pandemic, which has influenced the world, has affected the countries in manyareas. As in all countries under the influence of pandemic, education shave started to be provided through distance education in our country. In this research, it is aimed to try to under stand the experiences of science teachers working in secondary school in depth about what happened in distance education during COVID-19 pandemic process. In this context, the research was carried out with a phenomenology pattern, which is one of the qualitative research methods. Research working in middle schools in various regions of Turkey's 75 Science teachers were involved. First, the approval of Karamanoğlu Mehmetbey University Ethics Committee (95728670-044-E.10149) was obtained in order to collect the research data. The data were collected via "google drive" with a semi-structured interview form. The content analysis was taken as basis in the analysis of data. Some interpretations were made directly from the opinions and findings were supported by direct citations. As a result of the analysis, it was revealed that science teachers did not know what the pandemic was before the COVID-19 pandemic. It has been determined that they have problems such as internet connection in the distance education process, communicating with students, low participation rate of students and exposure to the pressure of school administration. In addition, besides the teaching methods and techniques used in the course of the distance education process, it was observed that the materials they used were changed, and they had concerns about not being able to complete the distance education program and laboratory / work shop activities. Also it was determined that the pandemic event mostly affected the use of educational Technologies and their Professional development positively. In this process, it was concluded that the teachers were anxious due to the lack of information that could occur in the students, they felt in sufficient in the distance education process, but they had the opportunity to improve themselves. Suggestions were made on to ward the results of the research.
\end{abstract}

\footnotetext{
*Araştırma T.C. Sağlık Bakanlığı Sağlık Hizmetleri Genel Müdürlüğü bünyesinde açılan Bilimsel Araştırma Platformu tarafından onaylanmışır.

*** Dr. Öğr. Üyesi, Karamanoğlu Mehmetbey Üniversitesi, Eğitim Fakültesi, Matematik ve Fen Bilimleri Eğitimi Bölümü Asst. Prof. Dr. Karamanoğlu Mehmetbey University, Faculty of Education, Department of Mathematics and Science Education ORCID 0000000179971018

busrabakioglu@gmail.com

**** Doç. Dr., Karamanoğlu Mehmetbey Üniversitesi, Eğitim Fakültesi, Matematik ve Fen Bilimleri Eğitimi Bölümü

Assoc. Prof. Dr., Karamanoğlu Mehmetbey University, Faculty of Education, Department of Mathematics and Science Education

ORCID 0000-0001-5064-6983

mustafacevik@kmu.edu.tr

Cite as/ Atıf: Bakioğlu, B., Çevik, M. (2020). COVID-19 pandemisi sürecinde fen bilimleri öğretmenlerinin uzaktan eğitime ilişkin görüşleri. Turkish Studies, 15(4), 109-129. https://dx.doi.org/10.7827/TurkishStudies.43502

Received/Geliş: 11 May/Mayıs 2020

Accepted/Kabul: 10August/Ağustos 2020

Copyright $(\mathrm{C}$ MDE, Turkey
} 
Structured Abstract: Introduction and Purpose: In the world COVID-19 case has started to increase social anxiety and worry in many countries (Lin, 2020). The COVID-19 pandemic directly affected our training activities and brought some anxiety with it. Because when this epidemic spread to the world, the majority of countries announced that schools were closed temporarily, and it was reported that approximately 1.6 billion children and young people were affected by the pandemic, which affects more than 91 percent of students worldwide (Miks \& McIlwaine, 2020). In Turkey, formal and non-formal education in schools closed as of 16 March is the biggest public area affected by pandemics. In order to provide an effective education and training in this field in Turkey as in other countries of the world, distance education using digital technology carries out this process. The presence of positive or negative situations related to distance education being carried out digitally will help us to present a more perfect education model now and in the future. In the literature, there are no studies in which science teachers' views on distance education are included in the pandemic process. In this context, the main objective is to gather the opinions of Science teachers who are working in Turkey in middle schools related to distance education they perform.

\section{Methodology}

The research was carried out with a phenomenology pattern, which is one of the qualitative research methods. The reason for the selection of the phenomenology method in the research is to try to understand the experiences of Science teachers in depth about what happened in distance education during the COVID19 pandemic process. In the analysis of the data collected in this direction, themes and codes were created and content analysis was carried out.

In this research, appropriate sampling method was used. Participants were 75 Science teachers working in public and private schools in Turkey. In the phenomenology studies, data are generally obtained through interviews (Yıldırım\&Şimşek, 2013). In this research, the data were obtained through a semistructured interview form. The interview form was created by the researchers. In the analysis of the data, content analysis method was used and quotations from the expressions given by the participants were made from time to time. The consistency of the analysis was figured out with the "Reliability=agreement/agreement + disagreement" formula proposed by Miles and Huberman.In the analysis of the outcomes, inter-rater agreement was found as .85 coefficient (29/29+7) for the interview form.

\section{Findings}

Science teachers who participated in the study on a voluntary basis stated that they did not know what the pandemic was (52\%), and those who stated that they knew the pandemic confused some diseases with the pandemic. According to the findings related to the second problem of the research, the majority of the participants $(68 \%)$ continue their education through distance education. The biggest problems of science teachers in distance education are software / hardware problems; internet connection, computer programs, computer accents and not knowing how to use the computer. According to the findings regarding the views of the science teachers on the teaching process in distance education, which is the third problem of the research, the most frequently used teaching methods in the distance education process are as follows. It has been determined that these are question and answer, problem solving and expository teaching approaches. In distance education, they mostly use digital documents (slide, essay, book etc.), web applications (z books etc.), educational information network (EBA) course content and various videos as teaching materials. According to the findings regarding the fourth problem of the research; It has been determined that the pandemic process positively affects the use of educational technologies in teachers' professional lives. It was concluded that anxiety was created in most of the process $(58.6 \%)$, it negatively affected their occupational satisfaction in the pandemic process, and on the contrary, a great part of their professional development $(84 \%)$ was positively affected. When the attitudes of the science teachers towards the occupation / major in the pandemic process were examined, the finding indicates that their attitudes $(58.6 \%)$ did not change.

\section{Conclusion and Discussion}

It was revealed that the majority of science teachers working in the middle schools participating in the research did not know about the pandemic, while those who knew did not know exactly what the pandemic was. This result is similar to the study of Wang et.al. (2020). The researchers reported that the Chinese people had no knowledge of the coronavirus and the COVID-19 pandemic in the first stage of the research they carried out in three stages through a social media platform called "Sina Microblog". It has been determined that the majority of science teachers participating in the study have performed distance education.

Turkish Studies, 15(4) 
This result is similar to teachers in other countries (China, Ireland, Georgia, Zambia, Ukraine, North Macedonia, Vietnam, America, etc.) (UNISEF, 2020). Science teachers' biggest problems in distance education are; software / hardware problems; internet connection, computer programs, computer accents and not knowing how to use the computer. According to the opinions of science teachers about the teaching process in distance education, the most frequently used teaching methods in distance education; questionanswer, problem solving and expository teaching. They mostly use digital documents (slide, essay, book etc.), web applications ( $\mathrm{z}$ books etc.), educational information network (EBA) course content and various videos as teaching materials. In distance education, this result is largely in line with the reports of researchers in some other countries (Basilaia \& Kvavadze, 2020; Burke \& Dempsey, 2020; Mulenga \& Marban, 2020; Roy, 2020). It has been determined that the use of educational technologies positively affects science teachers' professional lives in COVID-19 pandemic process. It can be said that this process stems from the fact that teachers compelled them to improve their use of technology. In the literature, it is reported that teachers had to use many technological hardware and software for distance education during the COVID-19 process (Mulenga \& Marban, 2020; UNESCO, 2020). It was found that science teachers were concerned about the failure to teach in the classroom environment in most of the process (58.6\%). Among the causes of this anxiety, they attributed the reasons such as lack of knowledge, unhappiness, insufficiency in distance education and failure to reach the student. They also stated that the pandemic process negatively affects their occupational satisfaction, and the main reason for this is the failure to work in distance education. They were asked in which direction the COVID-19 pandemic affected their professional development and it was revealed that a large part $(84 \%)$ had a positive effect on their professional development. As a result of this, they attributed that they had the opportunity to improve themselves in this process, because they were able to teach even in difficult conditions, and that they felt less confident in the distance education process.

Keywords: Science Education, COVID-19 Pandemic, ScienceTeachers, DistanceEducation, Phenomenology

Öz: Son günlerde, Dünya'yı etkisine alan COVID-19 pandemisiülkeleri birçok alanda etkisi altına almıştır. Bunların başında da eğitim gelmektedir. Pandeminin etkisi altında kalan bütün ülkelerde olduğu gibi ülkemizde de eğitimler uzaktan eğitim yoluyla verilmeye başlanmıştır. Bu araştırmada, COVID-19 pandemisi sürecinde uzaktan eğitimde neler yaşandığı konusunda ortaokulda görevli Fen Bilimleri öğretmenlerinin deneyimlerini derinlemesine anlamaya çalışılması amaçlanmıştır. Bu nedenle araştırma, nitel araştırma yöntemlerinden olgubilim deseni ile yürütülmüş̧ür. Araştırmaya Türkiye'nin çeşitli bölgelerindeortaokullarda görev yapan 75 Fen Bilimleri öğretmenleri katılmıştır. Araştırmanın verilerinin toplanabilmesi için ilk olarak Karamanoğlu Mehmetbey Üniversitesi Etik Kurulu onayı (95728670-044E.10149 sayılı) alınmıştır. Veriler, yarı yapılandırılmış görüşme formu ile "googledrive" üzerinden toplanmıştır. Verilerin analizinde içerik analizi yöntemi kullanılmış, yer yer görüşlerden direk alıntılar yapılarak yorumlamalara gidilmiş, bulgular, bu doğrudan alıntılarla desteklenmiştir. Analiz sonucunda COVID-19 pandemisi öncesinde Fen Bilimleri öğretmenlerinin pandeminin ne olduğunu bilmedikleri ortaya çıkmıştır. Uzaktan eğitim sürecinde internet bağlantısı, öğrencilerle iletişim kurma, öğrencilerin derslere katılım oranının düşük olması ve okul yönetimininbaskısına maruz kalma gibi problemlere sahip oldukları tespit edilmiştir. Bunun yanında uzaktan eğitim sürecinde derste kullandıkları öğretim yöntem ve tekniklerin yanında, kullandıkları materyallerinin değiştiği, uzaktan eğitim ile öğretim programını ve laboratuvar/ atölye etkinliklerini tamamlayamama gibi kaygılara da sahip oldukları görülmüştür. Yine pandemi olayının eğitim teknolojileri kullanımını ve mesleki gelişimlerini çoğunlukla olumlu yönde etkilediği belirlenmiştir. Bu süreçte öğretmenlerin öğrencilerde oluşabilecek bilgi eksiklikleri nedeniyle kaygılı oldukları, uzaktan eğitim sürecinde kendilerini yetersiz hissettikleri, buna rağmen kendilerini geliş̧irme firsatı yakaladıkları sonucuna ulaşılmıştır. Araştırma sonuçları doğrultusunda önerilerde bulunulmuştur.

Anahtar Kelimeler: Fen Eğitimi, COVID-19 Pandemisi, Fen Bilimleri Öğretmenleri, Uzaktan Eğitim, Olgubilim

\section{Giriş}

İnsanlık tarih boyunca birçok kez çeşitli kriz ve felaketlerle karşılaşmıştır. Bunlardan birisi de pandemidir. Pandemi, bir hastalığın bir kıta ya da birkaç ülke üzerinde aynı anda yaygın şekilde görülmesi, büyük salgın (Türk Dil Kurumu [TDK], 2020) olarak tanımlanmaktadır. Şuan içinde 
bulunulan yeni tip koronovirüs (COVID-19) salgını da bu felaketlerden biridir. Dünya Sağlık Örgütü (DSÖ) Covid-19 ismini "korona" için "CO", "virüs" için "VI", "hastalık" için ise "D" şeklinde tanımlamıştır (Türkiye Bilimler Akademisi [TÜBA], 2020). Aralık 2019 tarihinde Çin'in Hubei eyaletine bağlı Wuhan kentinden yayılmaya başlayan COVID-19 salgınını DSÖ, 11 Mart'ta "pandemi" olarak ilan etmiştir (DSÖ, 2020). Bu tarihten itibaren; sağlık, ekonomi, eğitim ve sosyal faaliyetlerimizde ciddi değişiklikler meydana gelmiştir. Dünya çapında hızla artmakta olan COVID-19 vaka sayısıyla, birçok dünya ülkesinde toplumsal kaygılar ve endişeler de artmaya başlamıştır (Lin, 2020). COVID-19 pandemisi özellikle eğitim faaliyetlerimizi doğrudan etkilemiş ve beraberinden bazı kaygıları da getirmiştir. Çünkü bu salgın dünyaya yayıldığında, ülkelerin çoğunluğu okulların geçici olarak kapatıldığını duyurmuş ve dünyadaki öğrencilerin yüzde 91 'inden fazlasını etkileyen pandeminin, yaklaşık 1,6 milyar çocuk ve gencin bundan etkilendiği rapor edilmiştir (Miks \& McIlwaine, 2020). Bu salgından etkilenen ülkelerden biri de Türkiye'dir. 2019 Milli Eğitim Bakanlığı (MEB) (2019) raporuna göre Türkiye, 18 milyon civarında öğrenciye ve 950 bin civarında öğretmene sahiptir. 16 Mart itibariyle kapatılan okullardaki örgün ve yaygın eğitim pandemiden etkilenen en büyük kamusal alandır. COVID-19 pandemisininin oluşturduğu karmaşadan dolayı ekonomilerini korumakla ilgilenen devletlerin çoğu dijital teknolojilerin kullanımını benimseyen acil durum önlem paketleri başlatarak eğitim sürecini idame ettirme yoluna girmişlerdir (Agnoletto \& Queiroz, 2020). Bu alanda etkili bir eğitim ve öğretimin sağlanabilmesi için diğer dünya ülkelerinde olduğu gibi Türkiye de dijital teknolojileri kullanarak uzaktan eğitimle bu süreci yürütmektedir.

Evde veya okulda uygun maliyetlerle, hemen erişilebilir bilgisayarlar, telefonlar, dizüstü bilgisayarlar ve tabletlerin kullanımı artmış özellikle politika yapıcılar ve farklı paydaşları COVID19 krizi sırasında öğrenmenin bu yönde sürdürülmesini beklemektedirler (Mulenga \& Marban, 2020). Perienen (2020), eğitim sektörünün neredeyse tüm yaşam alanlarını etkileyen teknolojinin bu süreçle birlikte bir paradigma değişikliğine tanıklık ettiğini öne sürmüştür. Benzer şekilde Türkiye'de 16 Mart tarihinde okulların kapatılmasıyla başlayan süreçte öğretmenler ve öğrenciler eğitim ve öğretim sürecinde hâlihazırda kullandıkları teknoloji ile daha yakından meşgul olmak durumunda kalmışlardır. COVID-19 pandemisi nedeniyle, öğretmenler ve akademisyenler, öğrencilere içerik öğretme ve içerik dağıtma yöntemlerini öğrenmek zorunda kalmıştır. COVID-19, dijital cihazları, çevrimiçi kaynakları, sosyal medya teknolojisini ve e-öğrenme etkinliklerinindaha etkin kullanımındabir katalizör olmuştur (Mulenga ve Marban, 2020). Ancak Agnoletto ve Queiroz (2020), "COVID-19 ve Eğitimdeki Zorluklar" başlıklı makalelerinde, dijitalleşme mantığının basit olmadığını vurguladıkları çalışmalarında acil durumlarda kullanımının benimsendiği "öğrenme teknolojileri" nin bir çıkış noktası olduğunun altını çizmişlerdir. Bu bağlamda uzaktan eğitim evden veya oturulan yerden gerçekleştirilen bir faaliyetten ziyade içinde birçok zorluk ve kısıtlamaları da barındırabilmektedir. Özellikle dersin yürütülmesinden sorumlu öğretmenlerin pandeminin getirdiği kısıtlamalar, yaşadıkları bölgedeki internet ve teknolojik alt yapının zayıf olma durumları, bilgisayar öz- yeterlikleri, uzaktan eğitime yönelik tutumları, kişisel bilgisayara sahip olma durumları, pandemi korku ve kaygı duyguları da düşünüldüğünde süreci uzaktan yürütmelerinde karşılaşabilecekleri güçlüklerin, araştırılması gereken bir konudur.

\section{İlgili Alanyazın}

İletişim teknolojilerinin küreselleşmesi küresel eğitim sisteminin oluşmasına neden olmuş; internet, fiber optik, bilgisayar, televizyon ve diğer bilişim sistemlerinde yaşanan baş döndürücü gelişmeler eğitimde yeni uygulamaların meydana gelmesini sağlamıştır (Kırık, 2014). Bunlardan biri de uzaktan eğitim uygulamasıdır. Uzaktan eğitim elektronik olan ya da olmayan sistemler aracılığıyla özel iletişim yöntemleri gerçekleştirilerek zaman ve mekân sınırlarını ortadan kaldıran birçok öğrenme faaliyetini kullanıcılara sunan planlı, tasarlanmış kapsamlı bir öğrenme faaliyetidir (Altıparmak, 2011). Çevrimiçi uzaktan eğitim ortamları sayesinde farklı özellik ve birikime sahip olan kişiler bu ortamların avantajlarından yararlanarak çağdaş yöntemlerle kolayca etkili eğitimler alabilmektedirler (Rovai \& Downey, 2010). Buna karşın uzaktan eğitimde öğretmen ve öğrenci ve 
yine akranlar arasındaki yararlı etkileşimin sınırlı olması ve bunun sonucu olarak motivasyon eksikliğinin ortaya çıkabilmesi gibi bazı olumsuzlukları da yapısında barındırdığı rapor edilmektedir (Çetin ve diğerleri, 2004; Uzoğlu, 2017). Uygun mekân, zaman ve koşulların mümkün olamadığı durumlarda her öğrencinin kaliteli eğitim alabilmesi ve yine eğitimde firsat eşitliğinden bahsedilebilmesi için uzaktan eğitimin yapılması gerekliliği ortaya çıkmaktadır (Şen, Atasoy \& Aydın, 2010). Özellikle yaşanmakta olan pandemi sürecinde uzaktan eğitimin kullanılması kaçınılmaz olmuştur. Alanyazın bu bağlamda tarandığında yeni tip koronavirüsün neden olduğu COVID-19 pandemisinden dolayı ilgili alanyazının doğrudan tıbbi çalışmalarla ilgili olduğu görülmektedir. Bunun nedeni, COVID-19'un hizla yayılma oranı ve insan hayatını tehdit etmesiyle her kesimini etkisi altın almasından kaynaklanmaktadır. Bu kabul edilebilir bir durumdur ancak sürecin eğitim açısından araştırılması bağlamında alanyazın, ilk olarak öğretmenleri ve onların sürece iliş̧kin görüşlerini araştırmalara dahil etmeden, eğitim ortamlarında hiçbir paradigma değişikliğinin başarıyla yansıtılamayacağını ortaya koymaktadır (Mulenga \& Marban, 2020). Bu bağlamda Iwai (2020), COVID-19 pandemisi sırasında çevrimiçi öğrenme üzerine bir çalışma yürütmüştür. Çalışmada sınıflar sanallaştığında öğrencilerin ne kazanacakları ya da ne kaybedecekleri üzerinde tartışmalara gitmiştir. Araştırmada COVID-19 pandemisinin rutin sanal eğitim sırasında ortaya çıkanların ötesinde zorluklar sunmaya devam edeceğini vurgulamıştır. Örneğin Zoom gibi platformlara hızlı geçişin öğretim programlarını olumsuz etkileyebileceği özellikle de internet ve bilgisayarda daha az donanımlı eğitimcileri zorluklara sürüklediğini dile getirmiştir. Yine bir ekranın ve mikrofonun aracılık ettiği bir sınıfı yönetmenin zorluklarından ötürü birçok eğitimcinin dersi yürütemediklerini rapor etmiştir. Eğitimcilerin çevrimiçi platformları kullanma bir kaos telaşı yaratırken, sanal bir sınıfın New York gibi büyük metropollerde öğrencilerin uzun yolculuklar yapmadan derse katılmalarına firsat tanıdığını, yurtlarda veya okullarda öğrencileri umumi alanlardan uzak tutarak hastalıktan kendilerini koruduklarının da altı çizilmiştir. Roy (2020) çocukların COVID-19pandemisi döneminde evden öğrenmelerine yardımcı olabilecek bazı ipuçları sunmuştur. Bunlardan biri de, öğretmenlerin bazı telekonferans olanaklarını indirmeleri gerektiğini (örn. Skype, Zoom, Lifesize...) ve dersleri bu programlar aracılığıyla uzaktan verebileceklerini rapor etmiştir. Pandemiden ötürü okulların kapanmasından bu yana, UNICEF, öğrencilerin sürekliliğini sağlamak, ebeveynlerin, bakıcıların ve öğretmenlerin karantina sırasında uzaktan eğitim kaynaklarına ve desteğe erişmelerine yardımcı olmak için uzaktan eğitim seçenekleriyle farklı ülkelerde eğitim ve bilim bakanlıklarını desteklemek için "Öğrenme Pasaportu" adlı uzaktan eğitim platformu kurmuştur (Miks \& Mcllwaine, 2020). Bu çalışma, COVID-19'dan etkilenen çocuklara ve gençlere evde eğitimlerine devam etmelerine yardımc1 olmak için UNICEF ve Microsoft tarafından başlatılan küresel öğrenme platformudur. Bu platform için yapılan çağrılara eğiticiler adım adım cevap vermiştir.

Burke ve Dempsey (2020) İrlanda da pandemi ile birlikte okulların kapanmasının öğretmenlere avantajlarının ve dezanatajlarının olduğunu rapor etmişlerdir. Avantaj olarak, dijital öğrenme dünyasını kucaklamak için bir fırsat olduğunu, çünkü onu keşfetmenin, kaynak ve öğrenme planlarınınyeniden temin edilmesinin ve oluşturulmasının pratik olması bakımından zaman kazandıracağı belirtilirken, dezavantajı olarak çevrimiçi öğrenimi sağlamak için eğiticilerin baskı altında olduklarınıveokullar yeniden açıldığında öğretim programlarının yetişmeme endişesini taşıdıklarını rapor etmişlerdir. Baytiyeh (2019), okulun kapatılması sırasında öğrenmenin ve iletişimin mümkün olan her şekilde sürdürülmesinin önemli olduğunu savunmuştur. Eğitimler her ne kadar uzaktan yapılıyor olsa da sosyal ilişkilerimizi dijital olarak da devam ettirmeliyiz. Çünkü COVID-19 kaygısının sosyal tutumları önemli ölçüde etkilediği bulunmuştur (Lee, 2020). Burke (2020), eğitimi yeniden şekillendirme çabasında, COVID-19 pandemisi sürecinde uygulanması gereken bazı önlemlerin olduğunu şiddetle öne sürmüştür. Bu önlemler arasında; e-postalar ve telefon görüşmeleri yoluyla öğrenciler, veliler, öğretmenler ve diğer personel ile iletişimi uzaktan sürdürmek olduğunu vurgulamıştır. 
COVID-19 pandemisi sürecinde çoğunlukla çalışmalar tıbbi alanlarda yapılmakta olup eğitim alanındaki çalışmalar kısıtlı denilebilir. Özellikle alanyazında Fen Bilimleri öğretmenlerin pandemi sürecinde uzaktan eğitime yönelik görüşlerine yer verildiği araştırmalarla karşılaşılmamıştır. Bu araştırmanın da temel amacı olan Türkiye'de ortaokullarda görev yapmakta olan Fen Bilimleri öğretmenlerinin gerçekleştirdikleri uzaktan eğitime ilişkin görüşlerinin alınmasının alanyazındaki bu boşluğu dolduracağı düşünülmektedir. Araştırmada cevabı aranan sorular 4 tema altında oluşturulmuştur.

1.Fen Bilimleri öğretmenlerin pandemiye yönelik ön bilgi düzeyleri nasıldır?

2.Fen Bilimleri öğretmenlerinin COVID-19 pandemisi sürecinde uzaktan eğitim gerçekleştirme durumları nedir? nelerdir?

2.1.Fen Bilimleri öğretmenlerinin uzaktan eğitim sürecinde karşılaştıkları problemler nelerdir?

3.Fen Bilimleri öğretmenlerinin uzaktan eğitimde öğretme sürecine yönelik görüşleri

3.1.Uzaktan eğitimde kullandıkları öğretim yöntem ve teknikleri nelerdir?

3.2.Uzaktan eğitimde kullandıkları öğretim materyalleri nelerdir?

3.3.Uzaktan eğitimin gerçekleştirilmesi esnasında kullandıkları mekân, zaman ve öğretim programlarına yönelik görüşleri nelerdir?

4.Fen Bilimleri öğretmenlerinin COVID-19 pandemisi sürecinde öğretmenlik mesleğine ilişkin görüşleri nelerdir?

4.1.Fen Bilimleri öğretmenlerinin COVID-19 pandemisisürecininin mesleklerine yönelik kayg1 ve doyum ile mesleki gelişimlerine etkisi nasıldır?

4.2.Fen Bilimleri öğretmenlerinin COVID-19 pandemi sürecinden sonra pedagojik açıdan yapmak istedikleri herhangi bir çalışma var mıdır?

\section{Yöntem}

Araştırma, nitel araştırma yöntemlerinden olgubilim (fenomenoloji) deseni ile yürütülmüştür. Olgubilim, yaşanmış deneyimi değerlendirmeye odaklanan bir yöntemdir (Jasper, 1994). Olgubilim çalışmalarında amaç, katılımcıların bir olgu ya da durum ile ilgili kişisel deneyimlerini irdeleyerek, olgu ya da durum hakkında daha genel bir anlayış ortaya koymaktır (Yıldırım \& Şimşek, 2013). Olgubilim deseni farkında olduğumuz ancak derinlemesine ve ayrıntılı bir anlayışa sahip olmadığımız olgulara odaklanmaktadır. Olgular yaşadığımız dünyada olaylar, deneyimler, algılar, yönelimler, kavramlar ve durumlar gibi çeşitli biçimlerde karşımıza çıkabilmektedir. Olgubilim, öncelikli olarak olgunun altında yatan ortak anlamları keşfetmek için bireyler tarafından deneyimlenmiş dünyayı tanımlamaya ve yaşanmış deneyimlerin özünü açıklamaya çalı̧̧maktadır (Baker, Wuest \& Stern, 1992). Bu çalışmada olgubilim yönteminin seçim nedeni; araştırmanın amacı olan COVID-19 pandemisi sürecinde uzaktan eğitimde neler yaşandığ konusunda Fen Bilimleri öğretmenlerinin deneyimlerini derinlemesine anlamaya çalışmaktır. $\mathrm{Bu}$ doğrultuda temalar ve kodlar oluşturulmuş ve içerik analizi yapılmıştır.

\section{Katılımellar}

$\mathrm{Bu}$ araştırmada uygun örnekleme yöntemi kullanılmıştır. Katılımcıları Türkiye'de devlet ve özel okullarda görev yapan Fen Bilimleri öğretmenleri oluşturmaktadır. Katılımcıların betimsel özelliklerine ilişkin bilgiler Tablo 1'de sunulmuştur. 
Tablo1: Katılımcıların Betimsel Özelliklerine İlişkin Bilgiler

\begin{tabular}{|c|c|c|}
\hline & Frekans & Yüzde (\%) \\
\hline \multicolumn{3}{|l|}{ Cinsiyet } \\
\hline Kadın & 53 & 70.7 \\
\hline Erkek & 22 & 29.3 \\
\hline \multicolumn{3}{|l|}{ Yaş } \\
\hline $25-30$ yaş & 13 & 17.3 \\
\hline $31-40$ yaş & 41 & 54.7 \\
\hline $41-50$ yaş & 15 & 20 \\
\hline $51-60$ yaş & 6 & 8 \\
\hline \multicolumn{3}{|l|}{ Hizmet Y1li } \\
\hline $1-5 \mathrm{y} 1 \mathrm{l}$ & 10 & 13.3 \\
\hline 6- 10 yıl & 25 & 33.3 \\
\hline $11-15 \mathrm{y} 11$ & 13 & 17.3 \\
\hline 16- 20 y1l & 10 & 13.3 \\
\hline 21 yıl ve üzeri & 17 & 22.7 \\
\hline \multicolumn{3}{|l|}{ Çalışılan Okul Türü } \\
\hline Devlet okulu & 67 & 89.3 \\
\hline Özel okul & 8 & 10.7 \\
\hline \multicolumn{3}{|c|}{ Uzaktan Eğitim ile İlgili Hizmetiçi Eğitim Aldınız mı? } \\
\hline Evet & 21 & 28 \\
\hline Hayır & 54 & 72 \\
\hline \multicolumn{3}{|c|}{ Evde İnternet Bağlantınız Var mı? } \\
\hline Evet & 69 & 92 \\
\hline Hayır & 6 & 8 \\
\hline \multicolumn{3}{|c|}{ Kişisel Bilgisayarınız Var mı? } \\
\hline Evet & 66 & 88 \\
\hline Hayır & 9 & 12 \\
\hline \multicolumn{3}{|c|}{ Pandemi Korku Düzeyiniz Nedir? } \\
\hline Çok Korkuyorum & 8 & 10.7 \\
\hline Korkuyorum & 44 & 58.7 \\
\hline Korkmuyorum & 19 & 25.3 \\
\hline Hiç Korkmuyorum & 4 & 5.3 \\
\hline
\end{tabular}

Tablo 1 incelendiğinde katılımcıların 53 (\%70.7)'ü kadın, 22 (\%29.3)'si erkektir. Katılımcıların yaşları 25-60 yaş arasında değişmektedir. Hizmet yılı 1-5 yıl olanlar 10 (\%13.3) kişi, 6-10 yıl olanlar 25 (\%33.3), 11-15 y1l olanlar 13 (\%17.3), 16-20 y1l olanlar 10 (\%13.3) ve hizmet yılı 21 yıl ve üzeri olanlar 17 (\%22.7) kişidir. 67 (\%89.3)'si devlet okulunda 8 (\%10.7)'i özel okulda görev yapmaktadır. Uzaktan eğitim ile ilgili hizmetiçi eğitim alanlar 21 (\%28) kişi iken, 54 (\%72) kişi bu konuda hizmetiçi eğitim almamıştır. Ayrıca 66 (\%88) katılımıının kişisel bilgisayarı varken, 9 (\%12)'unun kişisel bilgisayarı bulunmamaktadır. 69 (\%92)'unun evde internet bağlantıs1 bulunurken 6 (\%8)'sının bulunmamaktadır. Öğretmenlerden 8 (\%10.7)'i pandemiden çok korkuyorum, 44 (58.7)'ü korkuyorum, 19 (\%25.3)'u korkmuyorum ve 4 (\%5.3)'ü hiç korkmuyorum şeklinde pandemiden korku düzeylerini belirtmişlerdir.

\section{Veri Toplama Araçları}

Olgubilim çalışmalarında veriler genellikle görüşme yoluyla elde edilir (Yıldırım \& Şimşek, 2013). Bu araştırmada da veriler yarı yapılandırılmış görüşme formu ile elde edilmiştir. Görüşme formu araştırmacılar tarafindan oluşturulmuştur. Pilot çalışma olarak 5 Fen Bilimleri öğretmenine çalışma öncesinde hazırlanan form gönderilmiş ve görüşme formunun işlenirliği 
sınanmıştır. Pilot çalışma sonunda bazı maddelerde düzeltmeler ve eklemeler yapılarak form son haline getirilmiştir.

Görüşme formu dört bölümden oluşmaktadır. İlk bölüm katılımcıların betimsel özelliklerine ilişkin bilgileri açıklamaları istenen sorulardan oluşmaktadır. İkinci bölümde Fen Bilimleri öğretmenlerinin uzaktan eğitim sürecinde karşılaştıkları problemlerin neler olduğuna yönelik sorulara yer verilmiştir. Üçüncü bölümde, Fen Bilimleri öğretmenlerinin COVID-19 pandemisi sürecinde uzaktan eğitimde öğretme süreçlerine ilişkin görüşlerinin sorulduğu sorular yer almaktadır. Dördüncü bölüm ise Fen Bilimleri öğretmenlerinin COVID-19 pandemisi sürecinde öğretmenlik mesleğine ilişkin görüşlerine yönelik sorulardan oluşmaktadır. Birinci ve dördüncü bölümü uzaktan eğitim yapan ya da yapmayan tüm Fen Bilimleri öğretmenlerinin cevaplandırmaları istenmiştir. Uzaktan eğitim ile Fen Bilimleri dersi yapan öğretmenler ise tüm bölümlerdeki soruları cevaplandırmışlardır. Görüşme formuna ait bazı sorular aşağıda belirtilmiştir;

•Uzaktan eğitim sürecinde öğrencilerle ilgili problemler yaşadınız mı? Cevabınız "Evet" ise ne gibi problemler yaşadınız?

-Laboratuar/Atölye çalışmaları gerektiren kazanımları uzaktan eğitim ile öğrencilerinize verebiliyor musunuz? "Evet" ise nasıl? "Hayır" ise bu kazanımları öğrencilerinize nasıl edindirmeyi düşünüyorsunuz?

•Pandeminin mesleki gelişiminizi hangi yönde etkilediğini düşünüyorsunuz? Cevabınız "Olumlu" ise, nasıl? Açıklayınız. "Olumsuz" ise nedenini açıklayınız.

Görüşme formunda "ne gibi", "nasıl", "neden" sorularılyla olgu ve olaylar hakkında derinlemesine bilgiler edinilmesi amaçlanmıştır.

\section{Veri Toplama Süreci}

Araştırmanın verilerinin toplanabilmesi için ilk olarak Karamanoğlu Mehmetbey Üniversitesi Etik Kurulu onayı (95728670-044-E.10149sayılı) alınmıştır. Daha sonra araştırma soruları"googledrive" üzerinden hazırlanarak link oluşturulmuş ve Fen Bilimleri öğretmenlerinin üye olduğu "gmail grupları" ve "sosyal medya grupları"nda araştırma linki paylaşılmıştır. Araştırmaya katılmaya gönüllü olan Fen Bilimleri öğretmenlerince sorular cevaplandırılarak veriler elde edilmiştir. Veriler 2020 yılı Nisan ayı içerisinde toplanmıştır.

\section{Veri Analizi}

Verilerin analizinde içerik analizi yöntemi kullanılmış ve zaman zaman katılımcıların verdikleri ifadelerden alıntılar yapılmıştır. Analiz yapılmadan önce görüşme formuna verilen yanıtlar "googledrive" üzerinden indirilmiş herbir form adlandırılmış $(\mathrm{K} 1, \mathrm{~K} 2, \mathrm{~K} 3 \ldots)$ ve verilen yanıtların soru başlıklarının altında toplanılması sağlanmıştır. Araştırma sorularına göre temalar oluşturulmuştur. Daha sonra katılımcıların verdiği cevaplar benzerlik ve farklılıklarına göre gruplandırılmış ve olumlu ve olumsuz cevaplar birbirinden ayrılmıştır. Katılımcıların verdikleri cevaplardan kodlar oluşturularak analiz tamamlanmıştır.

\section{Geçerlik ve Güvenirlik}

Fen Bilimleri öğretmenleri (5) ve alan uzmanları (2) görüşme formundaki soruları inceleyerek formun kapsam (içerik) geçerliğine sahip olduğu kanısına varmışlardır. Başka bir alan uzmanından, dışarıda tema kalmayacak biçimde aynı temaları kavramsal kategorilerle karşılaştırması istenmiştir. Araştırmacıların yapmış olduğu karşılaştırmalar ile alan uzmanın yapmış olduğu karşılaştırmalar arasındaki tutarlılık kontrol edilmiştir. Görüş birliği ve görüş ayrılığı sayıları karşılaştırmalar yapılarak tespit edilmiş ve araştırmanın güvenirliği Miles ve Huberman'1n (1994) Güvenirlik=görüş birliği/(görüşbirliği+görüş ayrıllı̆̆)*100 formülü kullanılarak hesaplanmıştır. Miles ve Huberman (1994)'a göre kodlayıcılar arasında görüş 
birliğinin en az \%80 olması beklenir. Araştırmada kodlayıcılar arasında \%85 $(68 / 68+12)$ görüş birliğine varıldığ için araştırma güvenilirdir.

\section{Bulgular}

Fen Bilimleri öğretmenlerine yöneltilen sorulardan elde edilen bulgular araştırmanın problemlerine dayalı olarak 4 bölümde incelenmiştir.

\subsection{Fen Bilimleri Öğretmenlerinin Pandemi Hakkında Sahip Oldukları Ön Bilgiler}

Fen Bilimleri öğretmenlerine pandeminin ne olduğu konusunda COVID-19 pandemisiöncesinde bilgi sahibi olup olmadıkları sorulmuş ve bu konuda daha önce bilgi sahibiyseler bildikleri pandemi örneklerini yazmaları istenmiştir. Bu soruya öğretmenler bir ya da birden fazla örnek vermişlerdir. Öğretmenlerin verdikleri cevaplar kodlanmış ve Tablo 2 de sunulmuştur.

Tablo 2: Fen Bilimleri Öğretmenlerinin Pandemi Hakkında Sahip Oldukları Ön Bilgiler

\begin{tabular}{|c|c|c|}
\hline Ana Tema & Cevaplar & Kodlar \\
\hline $\begin{array}{l}\text { Pandemi hakkında } \\
\text { bilgi }\end{array}$ & $\begin{array}{l}\text { Pandemi hakkında ön bilgiye sahibim (36) } \\
\text { Pandemi hakkında ön bilgiye sahip değilim (39) }\end{array}$ & $\begin{array}{l}\text { *Sars (15) } \\
\text { *Veba (11) } \\
\text { *Ebola (8) } \\
\text { *İspanyol Gribi (6) } \\
\text { *Mers (4) } \\
\text { *Influenza (4) } \\
\text { *Domuz Gribi (4) } \\
\text { *Kuş Gribi (3) } \\
\text { *Kolera (3) } \\
\text { *Sitma (2) } \\
\text { *Şarbon (1) } \\
\text { *AIDS (1) } \\
\text { *Kara Humma (1) } \\
\text { *Sarı Humma (1) }\end{array}$ \\
\hline
\end{tabular}

Tablo 2 incelendiğinde 39 Fen Bilimleri öğretmeninin COVID-19 öncesinde pandemi hakkında herhangi bir ön bilgiye sahip olmadıkları, 36 öğretmenin ise COVID-19 öncesinde pandemi hakkında ön bilgiye sahip oldukları ifade edilmiștir. Pandemi konusunda daha önce bilgi sahibi olan öğretmenlerden pandemi örnekleri yazmaları istendiğinde öğretmenlerin en çok Sars (15), Veba (11), Ebola (8) ve İspanyol Gribi (6) ni örnek verdikleri görülmektedir. Sitma (2), AIDS (1), Şarbon (1) gibi hastalıklar pandemi olmamasına rağmen pandemi örneği olarak verilmiştir.

\subsection{Fen Bilimleri Öğretmenlerinin Uzaktan Eğitim Sürecinde Yaşadıkları Problemler}

Öncelikli olarak araştırma çerçevesinde Fen Bilimleri öğretmenlerinin uzaktan eğitim yapıp yapmadıkları sorulmuştur. Öğretmenlerin 51 (\%68)'i uzaktan eğitim yoluyla Fen Bilimleri dersi yaptıklarını ifade ederken, 24 (\%32)'ü uzaktan eğitim yoluyla Fen Bilimleri dersi yapmadıklarını belirtmişlerdir. Ayrıca Fen Bilimleri öğretmenlerinin uzaktan eğitim sürecinde bilgisayar (yazılım-donanım), internet bağlantısı, öğrenciler, zümreler, okul yönetimi ve okulun bağlı olduğu milli eğitim müdürlüğü/yetkilileri ile problem yaşayıp yaşamadıkları sorulmuştur. Öğretmenlerin verdikleri cevaplar temalandırılarak kodlar oluşturulmuş ve Tablo 3'de sunulmuştur. 
Tablo 3: Fen Bilimleri Öğretmenlerinin Uzaktan Eğitim Sürecinde Yaşadıkları Problemler

\begin{tabular}{|c|c|c|}
\hline Ana Tema & Cevaplar & Kodlar \\
\hline \multirow{4}{*}{$\begin{array}{l}\text { Bilgisayarla } \\
\text { (yazılım/donanım) } \\
\text { yaşanan problemler }\end{array}$} & Problem yaşamadım (25) & *İnternet Bağlantısı (4) \\
\hline & Problem yaşadım (18) & *Bilgisayar Programı (4) \\
\hline & Yanit yok (32) & *Bilgisayar aksanları (3) \\
\hline & & *Bilmeme (2) \\
\hline \multirow{3}{*}{$\begin{array}{l}\text { İnternet bağlantısı ile } \\
\text { yaşanan problemler }\end{array}$} & Problem yaşamadım (22) & *Bağlantı kopması (11) \\
\hline & Problem yaşadım (22) & *Bağlantı yavaşlı̆̆ \\
\hline & Yanit yok (31) & *Aşırı yoğunluk (5) \\
\hline \multirow{7}{*}{$\begin{array}{l}\text { Öğrenciler ile yaşanan } \\
\text { problemler }\end{array}$} & Problem yaşamadım (5) & *Öğrencinin internete/bilgisayara \\
\hline & Problem yaşadım (46) & erişememesi (16) \\
\hline & Yanit yok (24) & *Derslere katılım düşüklüğü (14) \\
\hline & & *Öğrencilerde motivasyon düşüklüğü/ \\
\hline & & *Öğgrenci-öğretmen iletişim zayıflığg (4) \\
\hline & & *Öğrencilerin programları bilmemesi (2) \\
\hline & & *Dersi sabote etme (2) \\
\hline \multirow{3}{*}{$\begin{array}{l}\text { Zümre ile yaşanan } \\
\text { problemler }\end{array}$} & Problem yaşamadım (65) & *İletişim kopukluğu (2) \\
\hline & Problem yaşadım (3) & *Bilgiyi paylaşmama (1) \\
\hline & Zümrem yok (7) & \\
\hline \multirow{5}{*}{$\begin{array}{l}\text { Okul yönetimi ile } \\
\text { yaşanan problemler }\end{array}$} & Problem yaşamadım (38) & *Bitmeyen istekler (3) \\
\hline & Problem yaşadım (10) & *Süreci bilmeme (2) \\
\hline & Yanit yok (27) & *Bask1 (2) \\
\hline & & *Beklenti yüksekliği (1) \\
\hline & & *Öğretmene danışmama (1) \\
\hline \multirow{3}{*}{$\begin{array}{l}\text { Milli eğitim } \\
\text { müdürlüğü/yetkilileri ile } \\
\text { yaşanan problemler }\end{array}$} & Problem yaşamadım (42) & *Bask1 (2) \\
\hline & Problem yaşadım (3) & *Süreci bilmeme (1) \\
\hline & Yanit yok (30) & \\
\hline
\end{tabular}

Tablo 3 incelendiğinde Fen Bilimleri öğretmenlerinin bilgisayarla (yazılım/donanım) yaşadıkları problemlerin; internet bağlantısı (4), bilgisayar programları (4), bilgisayar aksanları (3) ve bilgisayarı nasıl kullanacaklarını bilmeme (2) ile ilgili problemler yaşadıkları görülmektedir. K20öğretmen"MicrosoftTeams ile uzaktan eğitim vermem gerekiyordu. Ofis 365 hesab1 alma konusunda biraz zaman kaybım oldu. Bir süre konuk kimliği ile ders yaptım.” K32 öğretmen "Evet. Kişisel bilgisayarımın işletim sistemi düşük kaldı, Windows 7 yüklü." cevaplarını vermişlerdir.

Fen Bilimleri öğretmenleri internet bağlantısı ile yaşadıkları problemleri; bağlantı kopması (11), bağlantı yavaşlığı (6) ve aşırı yoğunluk (5) olarak ifade etmişlerdir. K11öğretmen "Çok yavaş olması, gündüz işlem yapılamaması (öğretmen veya öğrenci Eba'ya belirlenen saatlerde bile giremiyor)" K5 öğretmen "Ses ve görüntü sürekli olmasa da konsantrasyonu bazen bozacak şekilde gidip geldi." olarak cevaplar vermişlerdir.

Fen Bilimleri öğretmenlerinin uzaktan eğitim sürecinde öğrenciler ile yaşanan problemleri; öğrencinin internete/bilgisayara erişememesi (16), derslere katılım düşüklüğü (14), öğrencilerde motivasyon düşüklüğü/isteksizlik (7), öğrenci- öğretmen iletişim zayıflı̆̆ı (4), öğrencilerin programları bilmemesi (2) ve canlı dersleri sabote etmeleri (2) olarak açıklamışlardır. K60 öğretmen "Öğrencilerin tamamına yakınında kişisel teknolojik aracın olmaması veya internete erişim imkânının olmaması dersi bir bölüm öğrenciyle yapmamıza neden oluyor. Ayrıca öğrencilerin programlar ve kullanımıyla ilgili tam fikir sahibi olmaması da derslerin belirtilen 
saatlerde başlamasında ve bitmesinde gecikmelere neden oluyor."K1öğretmen "İsteksizler, motivasyonları düşük, interneti olmayan ya da mobil hattı çekmediği için internete bağlanamayan birçok öğrenci var. Ayrıca öğrencilerde Eba'ya nasıl gidilebileceği ile ilgili çok eksikler vardı."K25 öğretmen "Ekrana yansıtılan dosya üzerine gerekli gereksiz çizikler atmaları gibi şımarıklıklar." olarak yaşadıkları problemleri ifade etmişlerdir.

Fen Bilimleri öğretmenlerinin büyük çoğunluğu (65) zümreleri ile uzaktan eğitim sürecinde problem yaşamamışlardır. Problem yaşayan 3 öğretmen; iletişim kopukluğu (2) ve bilgiyi paylaşmama (1) konusunda problemler yaşamışlardır. K40 öğretmen "Zümrem ile ilgili iletişim problemi var." K70 öğretmen "Herhangi bilgi paylaşımı olmadı." olarak kendilerini ifade etmişlerdir.

Fen Bilimleri öğretmenlerinin büyük çoğunluğu (42) uzaktan eğitim sürecinde okul yönetimi ile problem yaşamamışlardır. Problem yaşayan 10 öğretmen, okul yönetiminin bitmeyen isteklerinden (3), süreci bilmemelerinden dolayı oluşan belirsizlikten (2), kendilerine bask1 yapılmasından (2), normal bir süreçteki gibi başarı beklentilerinin yüksek olmasından (1) ve ders saatleri konusunda öğretmene danışılmamasından (1) doğan problemler yaşamışlardır. K61öğretmen "Okul yönetiminin, öğrencinin olağan dış1 bir süreçte olduğunu kabul etmeyip, öğrencilerden sınıf ortamında ders işlenirken gösterilen performansı beklemesi gibi beklentilerinin olması ve bu beklentileri yüksek seviyede tutması bizlere evlerimizde daha çok stres yaşamaya itti." K2 öğretmen "Yönetimin Whatsapp ile gün içerisinde sürekli istekte bulunmas1, 7/24 öğretmenlik süreci çok bunalttı. Tuşlu telefona geçmek ve akıllı telefondan kurtulmak istiyorum artık."K8 öğretmen ise "Evet. Ders saatlerini kafasına göre atadı." olarak yaşadıkları problemleri ifade etmişlerdir.

Milli eğitim müdürlüğü/yetkilileri ile Fen Bilimleri öğretmenlerinin büyük bir bölümü (42) uzaktan eğitim sürecinde bir problem yaşamadıklarını söylemişlerdir. Problem yaşayan 3 öğretmen ise; milli eğitim yetkililerinin baskı yapması (2) ve süreci bilmemelerinden ötürü (1) problem yaşadıklarını ifade etmiş̧lerdir. K19 öğretmen "Uzaktan eğitim sürecinde okulunuzun bağlı olduğu milli eğitim müdürlüğünü de aradım fakat genel olarak bir bilgi eksikliği mevcuttu. Bu nedenle açıklayıc1 değillerdi.”K55 öğretmen "Çalışmadığımızı düşündüklerine yönelik mesajlar yolluyorlar." olarak soruya cevap vermişlerdir.

\section{Görüşleri}

\subsection{Fen Bilimleri Öğretmenlerinin Uzaktan Eğitimde Öğretme Sürecine İlişkin}

Uzaktan eğitim sürecinde Fen Bilimleri öğretmenlerine kullandıkları materyaller, yöntem ve tekniklerin neler olduğu, zaman, mekân ve öğretim programına ilişkin görüşlerinin neler olduğuna dair sorular sorulmuştur. Cevaplar temalandırılarak kodlar oluşturulmuştur (Tablo 4). 
Tablo 4: Fen Bilimleri Öğretmenlerinin Uzaktan Eğitimde Öğretme Sürecine İlişkin Görüşleri

\begin{tabular}{|c|c|c|c|}
\hline $\begin{array}{l}\text { Ana } \\
\text { Tema }\end{array}$ & Alt Tema & Cevaplar & Kodlar \\
\hline \multirow[t]{2}{*}{ Yöntem } & $\begin{array}{l}\text { Pandemi öncesi sınıf } \\
\text { ortamında derslerin } \\
\text { işlendiği yöntem }\end{array}$ & Yanit yok (20) & $\begin{array}{l}\text { *İşbirlikli (14) } \\
\text { *Soru- cevap (11) } \\
\text { *Problem çözme }(10) \\
\text { *Gösterip yaptırma (9) } \\
\text { *Tüm yöntemler (6) } \\
\text { *Modelleme (1) } \\
\text { *Örnek olay (1) }\end{array}$ \\
\hline & $\begin{array}{l}\text { Uzaktan eğitim } \\
\text { sürecinde derslerin } \\
\text { işlendiği yöntem }\end{array}$ & Yanit yok (14) & $\begin{array}{l}\text { *Soru-Cevap (14) } \\
\text { *Problem çözme (11) } \\
\text { *Düz anlatım (8) } \\
\text { *İşbirlikli (7) } \\
\text { *Video (3) } \\
\text { *Gösterip yaptırma (2) } \\
\text { *Whatsapp (2) } \\
\text { *Canlı Ders (2) } \\
\text { *Slayt(ppt) (1) } \\
\text { *Örnek olay (1) } \\
\text { *Eba üzerinden çalışma gönderme (1) }\end{array}$ \\
\hline \multirow[t]{2}{*}{ Materyal } & $\begin{array}{l}\text { Uzaktan eğitim } \\
\text { sürecinde derslerde } \\
\text { kullanılan materyaller }\end{array}$ & Yanit yok (24) & $\begin{array}{l}\text { *Dokümanlar (slayt, deneme, kitap vb.) } \\
\text { (26) } \\
\text { *Web Uygulamaları (z kitap vs.) (10) } \\
\text { *Eba ders içeriği (7) } \\
\text { *Video (6) } \\
\text { *Kâğıt-kalem (1) } \\
\text { *Hiç bir şey kullanmıyorum (1) }\end{array}$ \\
\hline & $\begin{array}{l}\text { Pandemi öncesinde } \\
\text { sinıf ortamında } \\
\text { derslerde kullanılan } \\
\text { materyaller }\end{array}$ & Yanit yok (23) & $\begin{array}{l}\text { *Akıllı tahta }(23) \\
\text { *Akıllı tahta + Deney malzemeleri (11) } \\
\text { *Deney malzemeleri }(9) \\
\text { *Ders materyalleri }(7) \\
\text { *Deney malzemeleri + Ders } \\
\text { materyalleri }(5) \\
\text { *Akıllı tahta + Deney malzemeleri + } \\
\text { Ders materyalleri (5) } \\
\text { *Tüm materyaller (1) }\end{array}$ \\
\hline $\begin{array}{l}\text { Ders } \\
\text { süresi }\end{array}$ & $\begin{array}{l}\text { Uzaktan eğitim } \\
\text { sürecinde } 1 \text { dersin } \\
\text { tamamlandığ } 1 \text { zaman } \\
\text { (dakika) }\end{array}$ & Yanit yok (25) & $\begin{array}{l}* 1-30 \mathrm{dk}(14) \\
* 31-60 \mathrm{dk}(33) \\
* 61-90 \mathrm{dk}(2) \\
* 91 \mathrm{dk} \text { ve üzeri (1) }\end{array}$ \\
\hline Mekân & $\begin{array}{l}\text { Uzaktan eğitimin } \\
\text { verildiği mekân }\end{array}$ & $\begin{array}{l}\text { Yanit yok (21) } \\
\text { Ev (53) } \\
\text { Ofis (1) }\end{array}$ & $\begin{array}{l}\frac{\text { Ev }(53)}{* \text { Dişarı çıkamama }(14)} \\
\text { *Rahat (1) } \\
\text { *Güvenli (1) } \\
\text { *Okula uzak olma (1) } \\
\frac{\text { Ofis (1) }}{* \text { Mecburiyet }(1)}\end{array}$ \\
\hline $\begin{array}{l}\text { Öğretim } \\
\text { programı }\end{array}$ & $\begin{array}{l}\text { Uzaktan eğitim ile } \\
\text { öğretim programının }\end{array}$ & $\begin{array}{l}\text { Yanit yok (20) } \\
\text { Tamamlayabilirim (20) }\end{array}$ & $\frac{\text { Tamamlayabilirim }(20)}{{ }^{*} \text { Online iletişim }(7)}$ \\
\hline
\end{tabular}




\begin{tabular}{|c|c|c|}
\hline tamamlanması & $\begin{array}{l}\text { Tamamlayamam (23) } \\
\text { Kismen Tamamlayabilirim } \\
(12)\end{array}$ & $\begin{array}{l}\text { *Kalan konuların kolay olması (4) } \\
\text { *Video göndererek (1) } \\
\text { *Sisteme alışma (1) } \\
\text { *Ders süresinin yetmesi (1) } \\
\text { Tamamlayamam (23) } \\
\text { *Ortamın uygun olmaması (8) } \\
\text { *Öğrencilerin pasif olması (6) } \\
\text { *Ders süresinin yetmemesi (4) } \\
\text { Kısmen Tamamlayabilirim (10) } \\
\text { *Verimliliğin düşük olması (6) } \\
\text { *Tüm öğrencilere ulaşılamaması (4) }\end{array}$ \\
\hline $\begin{array}{l}\text { Laboratuvar/atölye } \\
\text { çalışmalarını uzaktan } \\
\text { eğitim ile } \\
\text { tamamlanması }\end{array}$ & $\begin{array}{l}\text { Yanit yok (20) } \\
\text { Tamamlayabilirim (26) } \\
\text { Tamamlayamam (18) } \\
\text { Kismen Tamamlayabilirim } \\
\text { (4) }\end{array}$ & $\begin{array}{l}\text { Tamamlayabilirim (26) } \\
\text { *Video göndererek (12) } \\
\text { *Online iletişim (5) } \\
\text { *Eba deney videoları ile (4) } \\
\text { *Evde yapmalarını isteyerek (4) } \\
\text { *Slayt göndererek (1) } \\
\text { Tamamlayamam (23) } \\
\text { *Fikrim yok (5) } \\
\text { *Evde yapmalarını isteyerek (5) } \\
\text { *Telafi eğitimi (4) } \\
\text { *Video önererek (4) } \\
\text { Kısmen Tamamlayabilirim (10) } \\
\text { *Simülasyonlarla (2) } \\
\text { *Evde yapmalarını isteyerek (2) }\end{array}$ \\
\hline
\end{tabular}

Tablo 4 incelendiğinde Fen Bilimleri öğretmenlerinin COVID-19 pandemisi öncesi sınıfta en çok kullandıkları öğretim yöntemlerinin; işbirlikli (14), soru- cevap (11), problem çözme (10), gösterip yaptırma (9) olduğu görülürken, uzaktan eğitim sürecinde en çok kullandıkları öğretim yöntemlerinin ise; soru-cevap (14), problem çözme (11), düz anlatım (8), işbirlikli (7) olduğu görülmektedir. Ayrıca Fen Bilimleri öğretmenleri; Whatsapp (2), canlı ders (2), Eba üzerinden çalışma gönderme (1)'yi de öğretim materyali olarak görmektedirler.

Fen Bilimleri öğretmenleri pandemi öncesi sınıf ortamında öğretim materyali olarak en çok; ak1llı tahta (23), akıllı tahta + deney malzemeleri (11), deney malzemeleri (9), ders materyalleri (7) kullanmaktadırlar. Uzaktan eğitim sürecinde ise; dokümanlar (slayt, deneme, kitap vb.) (26), Web uygulamaları (z kitap vs.) (10), Eba ders içeriği (7), videolar (6)'ı öğretim materyali olarak kullanmaktadırlar.

Tablo 4 incelendiğinde Fen Bilimleri öğretmenleri uzaktan eğitim sürecinde 1 derslerini daha çok 31-60 dakika arasında tamamladıkları görülmektedir. Ayrıca Fen bilimleri öğretmenleri uzaktan eğitimlerini evde (53) verdikleri görülmektedir. Buna neden olarak dışarıya çıkamama (14), evin rahat (1) ve güvenli (1) olmasını göstermişlerdir. Farklı olarak Fen Bilimleri öğretmenlerinden bir tanesi uzaktan eğitim derslerini mecburen ofiste verdiğini ifade etmiştir.

Uzaktan eğitim ile öğretim programını tamamlama konusunda Fen Bilimleri öğretmenlerinin 20'si öğretim programını tamamlayabileceğini düşünürken, 23'ü tamamlayamayacağını, 12'si ise kısmen tamamlanabileceğini ifade etmişlerdir. Uzaktan eğitim ile öğretim programını tamamlayabileceğini düşünen Fen Bilimleri öğretmenleri buna neden olarak; online iletişimle (7), kalan konuların kolay olması (4), video göndererek (1), sisteme alışma (1), ders süresinin yetmesi (1)'ni göstermişlerdir. Uzaktan eğitim ile öğretim programını tamamlayamayacağını düşünen fen bilimleri öğretmenleri buna neden olarak; ortamın uygun olmaması (8), öğrencilerin pasif olması (6), ders süresinin yetmemesi (4)'ni göstermişlerdir. Uzaktan eğitim ile öğretim programını kısmen tamamlayabileceğini düşünen fen bilimleri 
öğretmenleri buna neden olarak; uzaktan eğitimle verimliliğin düşük olmasını (6), tüm öğrencilere ulaşılamaması (4) göstermişlerdir.

Fen Bilimleri öğretmenlerinin 26'sı laboratuvar/ atölye çalışmalarını uzaktan eğitim ile tamamlayabileceğini düşünürken, 18 öğretmen tamamlayamayacağını, 4 öğretmen ise kısmen tamamlanabileceğini ifade etmişlerdir. Laboratuvar/ atölye çalışmalarını uzaktan eğitim ile tamamlayabileceğini düşünen Fen Bilimleri öğretmenleri bunu, video göndererek (12), online iletişimle (5), Eba deney videoları ile (4), evde yapmalarını isteyerek (4), slayt göndererek (1) tamamlayabileceklerini ifade etmişlerdir. Laboratuvar/ atölye çalışmalarını uzaktan eğitim ile tamamlayamayacağını düşünen Fen Bilimleri öğretmenleri ise bu çalışmaları öğrencilere; evde yapmalarını isteyerek (5), telafi eğitimi (4), video önererek (4) kazandıracaklarını ifade etmişlerdir. 5 Fen bilimleri öğretmeni ise uzaktan eğitim ile yapamadıkları laboratuvar/ atölye çalışmalarını nasıl öğrencilere kazandıracakları konusunda bir fikirlerinin olmadıklarını söylemişlerdir. Laboratuvar/ atölye çalışmalarını uzaktan eğitim ile kısmen tamamlayabileceğini düşünen Fen Bilimleri öğretmenleri bu çalışmaları öğrencilere; simülasyonlarla (2), deneyleri evde yapmalarını isteyerek (2) telafi edebileceklerini ifade etmişlerdir.

\subsection{Fen Bilimleri Öğretmenlerinin COVID-19 Pandemisi Sürecinde Öğretmenlik Mesleği Hakkındaki Görüşleri}

Fen Bilimleri öğretmenlerinin COVID-19 pandemisi sürecinin öğretmenlik mesleğine yönelik kaygı, doyum, tutum, eğitim teknolojilerini kullanmasına etkileri araştırılmıştır. Ayrıca Fen Bilimleri öğretmenlerinin pandemiden sonra okulda yapmak istedikleri çalışmaların neler olduğu öğretmenlere sorulmuştur. Bu doğrultuda temalar oluşturulmuş ve kodlamalar yapılmıştır. Oluşturulan temalar ve kodlar Tablo 5'te sunulmuştur.

Tablo 5: Fen Bilimleri Öğretmenlerinin COVID-19 Pandemisi Sürecinde Öğretmenlik Mesleği Hakkındaki Görüşleri

\begin{tabular}{|c|c|c|}
\hline Ana Temalar & Cevaplar & Kodlar \\
\hline Eğitim teknolojileri & Etkilemedi (26) & *Teknoloji kullanımının artması (11) \\
\hline \multirow[t]{2}{*}{ kullanımı } & Etkiledi (38) & *Online platformları kullanmaya başlama (10) \\
\hline & Yanit yok (10) & *Farklı programları keşfetme (9) \\
\hline \multirow[t]{3}{*}{ Kayg1 } & Kaygilıyım (44) & *Öğrencide oluşabilecek bilgi eksikliği (22) \\
\hline & Kaygılı değilim (16) & *Mutsuz olma (10) \\
\hline & Yanit yok (5) & $\begin{array}{l}\text { *Uzaktan eğitimde kendini yetersiz hissetme (5) } \\
\text { * Öğrenciye ulaşamama (5) }\end{array}$ \\
\hline \multirow[t]{7}{*}{ Mesleki doyum } & Etkilemedi (19) & Olumsuz Etkiledi (37) \\
\hline & Etkiledi (49) & *İşe yaramama hissi (17) \\
\hline & Yanit yok (7) & *Yüz yüze eğitimden yoksunluk (13) \\
\hline & & *Öğrencilerle iletişim kuramama (7) \\
\hline & & Olumu Etkiledi (7) \\
\hline & & *Kendini geliştirmeye vakit ayırabilme (5) \\
\hline & & * Daha aktif olma (2) \\
\hline \multirow[t]{11}{*}{ Mesleki gelişim } & Etkilemedi (4) & Olumsuz Etkiledi (15) \\
\hline & Etkiledi (63) & *İşe yaramama hissi (5) \\
\hline & Hem olumlu hem & *Bilgi körelmesi yaşanması (3) \\
\hline & olumsuz etkiledi (4) & *Herkesin farklı uygulama kullanması (2) \\
\hline & Yanıt yok (4) & *Okula özlem duyma (2) \\
\hline & & *Korku (1) \\
\hline & & *Boşluk hissi (1) \\
\hline & & *Öğrenciyle iletişimde zorluk (1) \\
\hline & & Olumlu etkiledi (36) \\
\hline & & *Kendini geliştirme firsatı (27) \\
\hline & & *Kendine güven duygusunun gelişmesi (5) \\
\hline
\end{tabular}




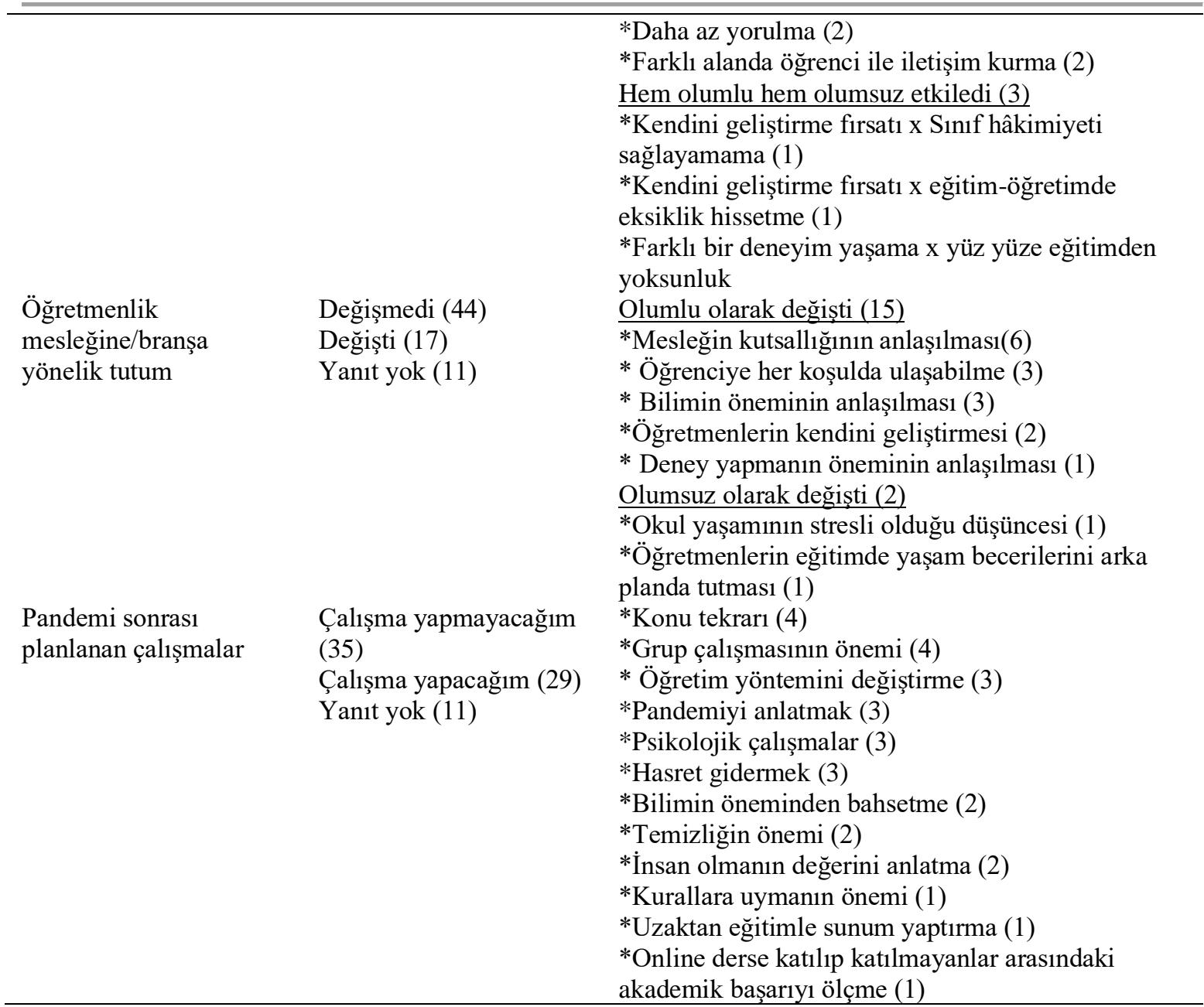

Tablo 5 incelendiğinde Fen Bilimleri öğretmenlerinin pandemi sürecinin eğitim teknolojileri kullanımını olumlu yönde etkilediği görülmektedir. Fen Bilimleri öğretmenleri pandemi sürecinde; farklı programları keşfetme (9), online platformları kullanmazken kullanmaya başlama (10) ve teknolojiyi kullanımın zamanında artma (11) meydana geldiğini ifade etmişlerdir. K33 öğretmen "Bir sürü uygulama yükleyip denedim, işime yaramayan veya kullanımı kolay olmayan programları eledim." K28 öğretmen"Bilmediğim bazı programları ve uygulamaları kullanmak durumunda kaldım" olarak cevaplar vermişlerdir.

Sınıf ortamında öğretmenlik yapamamanın Fen Bilimleri öğretmenlerinin büyük bir kısmında (44) kaygı oluşturduğu Tablo 5'te görülmektedir. Kayg1 nedenleri arasında öğrencide oluşabilecek bilgi eksikliği (22), mutsuz olma (10), uzaktan eğitimde kendini yetersiz hissetme (5), öğrenciye ulaşamama (5) olarak göstermişlerdir. K43 öğretmen "Evet, öğrencilerin iç disiplini olmaması, ne kadar içerik hazırlasanız da yapmamaları beni öğrenmenin tamamlanmaması açısından kaygılandırıyor.”K7 öğretmen "Evet. Öğrencilerime yeteri kadar destek olamadığımı düşünüp kaygı duyuyorum" şeklinde sorulara cevap vermişlerdir.

Fen Bilimleri öğretmenlerinin büyük bir kısmının (67) pandemi sürecinde mesleki doyumlarının olumlu veya olumsuz olarak etkilendiği Tablo 4'de görülmektedir. Olumsuz etkiledi (37) diyenler; uzaktan eğitim sürecinde işe yaramama hissi (17), yüz yüze eğitimden yoksunluk (13), öğrencilerle iletişim kuramama (7) olarak nedenler belirtirken, pandemisürecinde mesleki doyumları olumu etkilenenler (7); kendini geliştirmeye vakit ayırabildiklerini (5), öğrencilerle iletişimde daha aktif olduklarını (2) ifade etmişlerdir. K74 öğretmen "Uzaktan eğitimler meslek 
doyumu konusunda bana çok yardımcı oluyor. Hatta daha fazla soru incelemeye vakit buluyorum. İlgi isteyen öğrencilerime de daha fazla vakit ayırabiliyorum. Ayrıca öğrenciler uzaktan eğitim sayesinde kendilerini çok değerli hissediyorlar."K38 öğretmen "Evde kalmakla kendimi yetersiz bir öğretmen gibi hissediyorum. Öğrencilerime telefon, whatsapp, bilgisayar gibi araçlardan ulaşmaya çalışsam da sınıf ortamı olmadan her şey eksik kalıyor" şeklinde sorulan soruya cevap vermişlerdir.

COVID-19 pandemisinin mesleki gelişimlerini hangi yönde etkilediği Fen Bilimleri öğretmenlerine sorulmuş ve büyük bir kısmının (63) mesleki gelişimlerine olumlu etkilediği ortaya çıkmıştır. Buna neden olarak; kendilerini geliştirme fırsatı bulduklarını (27), zor durularda da ders verebildikleri için kendilerine güven duygusunun gelişmesini (5), uzaktan eğitim sürecinde daha az yorulduklarını (2) ve farklı alanda öğrenci ile iletişim kurmanın (2) onları geliştirdiklerini söylemişlerdir. COVID-19 pandemisinin mesleki gelişimlerini olumsuz olarak (15) etkilediğini düşünün Fen Bilimleri öğretmenleri buna neden olarak; işe yaramama hissi (5), bilgi körelmesi yaşanması (3), herkesin farklı uygulama kullanması (2), okula özlem duyma (2), korku (1), boşluk hissi (1), öğrenciyle iletişimde zorluk (1) olarak ifade etmişlerdir. Ayrıca bu sürecin mesleki gelişimlerini hem olumlu hem olumsuz etkilediğini ifade eden (3) Fen bilimleri öğretmenleri de vardır. Buna neden olarak; kendini geliştirme firsatı x sınıf hâkimiyeti sağlayamama (1),kendini geliştirme firsat1 x eğitim-öğretimde eksiklik hissetme (1), farklı bir deneyim yaşama x yüz yüze eğitimden yoksunluk olarak belirtmişlerdir. K11 öğretmen "Olumlu, pek çok yeni teknoloji hakkında bilgi sahibi oldum. Bunları da aktif bir şekilde kullandım. Gelişen teknolojiye ayak uydurmak beni mutlu etti.” K53 öğretmen "Olumsuz olarak fen konularımızı anlatamamak konuları pekiştiremememize sebep oluyor Bilgi körelmesi yaşıyorum.” K26 öğretmen ise "İki türlü de etkiledi evde kaldığımız için bazı eksiklikler oluşuyor eğitim öğretim sürecinde ancak uzaktan öğretim sürecinde online eğitim konusunda kendimizi geliştirdik" K66 öğretmen ise "Mesleki gelişimimi etkilediğini düşünmüyorum. Sonuçta doğum izni, sağlı izni gibi bazı sebeplerle görevden ayrıldığımız durumlar oluyor. Ayrıca hala uzaktan hizmetiçi eğitimler var. İsteyen katılabiliyor. Tabi bu eğitimler daha da artırılabilir.”olarak soruya cevap vermişlerdir.

Pandemi sürecinde Fen Bilimleri öğretmenlerinin öğretmenlik mesleğine/ branşına yönelik tutumları incelendiğinde büyük çoğunluğunun (44) tutumunun değişmediği Tablo 5'te görülmektedir. Tutumu değişenler ise olumlu ve olumsuz yönde değişimler yaşamışlardır. Olumlu şekilde tutumu değişenler buna neden olarak; mesleğin kutsallığının anlaşılması(6), öğrenciye her koşulda ulaşabilme (3), bilimin öneminin anlaşılması (3), öğretmenlerin kendini geliştirmesi (2), deney yapmanın öneminin anlaşılması (1) olarak ifade etmişlerdir. Tutumları olumsuz olarak değişenler ise; okul yaşamının stresli olduğu düşüncesi (1) ve öğretmenlerin eğitimde yaşam becerilerini arka planda tutması (1)'nı neden olarak göstermişlerdir. K61 öğretmen "Evet oldu. Öğretmenlik mesleğine karşı olumsuz tutum geliştirmeye başladım... Gerçekten okul ortamı ve dolayısıyla mesleğim beni oldukça strese sokuyormuş. Veli-öğrenci-öğretmen-idare ile birebir temas halinde olmak bana çok ağır geliyormuş. Şu an gayet resmi ve gerektiği miktarda o insanlarla görüşmek beni rahatlattı.” K1 öğretmen "Evet oldu. Ne kadar kutsal bir meslek olduğunu ve yüz yüze eğitim verebilmenin ne kadar önemli olduğunu daha iyi anladım." K13 öğretmen ise "Tutumum değişmedi. Yüz yüze eğitim dönemi başladığında öğrencilerimizle kaldığımız yerden devam edeceğiz.”ş̧eklinde soruya cevap vermişlerdir.

Pandemi sonrası bazı Fen Bilimleri öğretmenleri sınıfta çalışma yapmayı planlarken (29), bazılarının böyle bir planı olmadığı (35) Tablo 5'te görülmektedir. Bu çalışmalar; konu tekrarı (4), grup çalışmasının önemi (4), öğretim yöntemini değiştirme (3), pandemiyi anlatma (3), psikolojik çalışmalar (3), hasret giderme (3), bilimin öneminden bahsetme (2), temizliğin önemi (2), insan olmanın değerini anlatma (2), kurallara uymanın önemi (1), uzaktan eğitimle sunum yaptırma (1), online derse katılıp katılmayanlar arasındaki akademik başarıyı ölçme (1) gibi çalışmalardır. K39 öğretmen "Evet, işlenen konuların etkinlikleri yapılacak çünkü pandemiden dolayı çocuklarda bir kopma meydana geldi en azından bu etkinliklerle ilgileri daha da arttırılabilir. 7. sinıflarda 
merceklerle ilgili etkinlikler 5. sınıflarda 1şık ile ilgili etkinlikler.” K59 öğretmen "Evet. Bilim insanları ve çalışmaları ile ilgili etkinlikler. Bilimin değerini önemini anlamaları için mükemmel bir süreç" K36 öğretmen ise "Öğrencilerimle koşup oynayacağız zor bir süreçten geçtik çünkü" şeklinde sorulara cevap vermişlerdir.

\section{Sonuç ve Tartışma}

$\mathrm{Bu}$ bölümde araştırmanın problemleri doğrultusunda ulaşılan sonuçlar bulgular ışığında tartışılmıştır. Araştırmaya gönüllülük esasına göre katılan ortaokullarda görevli 75 Fen Bilimleri öğretmenlerinin yarıdan fazlasının (\%52) pandeminin ne olduğunu bilmediklerini dile getirmişler, pandemiyi bildiğini ifade edenlerin ise bazı hastalıkları pandemi ile karıştırdıkları ortaya çıkmıştır (AIDS, sıtma, şarbon vb.). Dolayısıyla araştırmaya katılan Fen Bilimleri öğretmenlerinin büyük kısmının pandemi hakkında herhangi bir ön bilgiye sahip olmadıkları söylenebilir. Benzer şekilde Wang, Di, Ye ve Wei (2020)“Sina Microblog” adlı bir sosyal medya platformundan üç aşamada gerçekleştirdikleri araştırmanın ilk fazında Çin halkının, coronavirüseve COVID-19 pandemisine ilişkin bilgilerinin olmadığını rapor etmişlerdir.

Araştırmanın ikinci problemine ilişkin bulgulara göre katılımcıların büyük çoğunluğu (\%68) uzaktan eğitim yoluyla öğretime devam etmektedirler. Uzaktan eğitim gerçekleștiren Fen Bilimleri öğretmenlerinin uzaktan eğitimde yaşadıkları en büyük problemlerinin bilgisayarla ilgili olarak yazılım/donanım problemleri; internet bağlantısı, bilgisayar programları, bilgisayar aksanlarıve bilgisayarı nasıl kullanacaklarını bilmeme olduğu sonucuna ulaşılmıştır. Bu sonuç Burke ve Dempsey (2020) hazırladıkları İrlanda'ya ait COVID-19 pandemisine ilişkin raporla da örtüşmektedir. İrlanda'da görev yapan öğretmenlerin hepsinin uzaktan eğitime yönelik becerilere tam sahip olmadıkları ve donanım, yazılım ve teknolojik becerilere ilişkin çeşitli problemlere sahip olduklarını rapor etmişlerdir. Agnoletto ve Queiroz'un (2020) belirttiği gibi “Dijitalleşme" mantığ1 basit değildir. İvedi olma, uzaktan yönetim sistemi, çevrimiçi öğretim araçları ile ilgili hazırbulunuşluk, dijital akıcılık ve bunların yanında korku ve sosyal izolasyondan kaynaklanan çeşitli olumsuz duygularla başa çıkma zorunluluğu gibi karmaşık bir yapıya sahiptir. Araştırmaya katılan Fen Bilimleri öğretmenlerinin uzaktan eğitimde yaşadıkları diğer en büyük problem öğrencilerle olanlardır. Öğretmenler öğrencinin internete/bilgisayara erişemediklerini, öğrencilerin çevrim içi veya çevrim dışı derslere katılımlarının az olduğunu ve öğrencilerde motivasyon düşüklüğünün olduğunu belirtmişlerdir. Ulaşılan bu sonuç Sintema (2020) ile paralellik göstermektedir. Araştırmac1 COVID-19 pandemisi sürecinde öğrencilerin öğretmenlerle olan iletişim becerilerinin zayıf olduğunu yine e-öğrenme olanaklarının eksikliğinden kaynaklı performans düşüklüğünün olduğunu rapor etmiştir. Araştırmada ulaşılan bir diğer bulgu ise Fen Bilimleri öğretmenlerinin büyük çoğunluğunun bu süreçte zümreleriyle, okul yönetimiyle ve il/ilçe Milli Eğitim Müdürlükleriyle herhangi bir sorun yaşamadıklarını belirtmişlerdir.

Araştırmanın üçüncü problemi olan Fen Bilimleri öğretmenlerinin uzaktan eğitimde öğretme sürecine ilişkin görüşlerine yönelik bulgulara göre uzaktan eğitim sürecinde en çok kullandıkları öğretim yöntemlerinin ise; soru-cevap, problem çözme ve düz anlatım olduğu tespit edilmiştir. Uzaktan eğitimde en çok dijital dokümanlar (slayt, deneme, kitap vb.), web uygulamaları (z kitap vs.), eğitim bilişim ağ 1 (EBA) ders içeriği ve çeşitli videolarıöğretim materyali olarak kullanmaktadırlar. Bu sonuç diğer bazı ülkelerdeki araştırmacıların raporlarında öğretmenlerin kullandıkları yöntem ve materyallerle debüyük oranda paralellik göstermektedir (Basilaia \& Kvavadze, 2020; Burke \& Dempsey, 2020; Mulenga \& Marban, 2020; Roy, 2020). Avrupa Birliği ülkelerinde de benzer uygulamaların olduğunu söyleyen MotiejūnaitèSchulmeisterve Crosier (2020), bazı Avrupa ülkelerinde okuldan alınan kitaplar ve materyaller aracılığıyla eğitim uzaktan sürdürülürken büyük çoğunluğunda, öğretmenlerin ve öğrencilerin birlikte çalışabilmelerini ve etkileşime girebilmelerini sağlayan çeşitli e-öğrenme platformları aracılığıyla ve hızla geliştirilen ulusal televizyon programları veya sosyal medya platformlarındaki derslerin yardımıyla sürdürüldüğünü ifade etmişlerdir. Öğretmenlerin uzaktan verdikleri eğitimleri 
sınıf ortamına göre daha pratik verdikleri ve pandeminin getirdiği kısıtlamalardan ötürü çoğunlukla evden eğitimleri yürüttükleri sonucuna ulaşılmıştır. Uzaktan eğitim ile öğretim programını tamamlama konusunda Fen Bilimleri öğretmenlerinin bir kısmı (\%26.6) öğretim programını tamamlayabileceğini düşünürken, diğer bir kısmı (\%30.6) tamamlayamayacağını, geri kalanlar ise (\%16) kısmen tamamlanabileceğini ifade etmişlerdir. Öğretim programını tamamlayamayacaklarını ifade edenler ortamın uygun olmadığı, öğrenci katılımlarının az olduğu ve sürenin yetersiz olduğu gibi gerekçelere dayandırmışlardır. Laboratuvar veya atölye çalışmalarını uzaktan eğitim ile tamamlayabileceklerini düşünen öğretmenlerin çoğunlukta olduğu tespit edilmiştir. $\mathrm{Bu}$ tarz uygulamalı çalışmaları video göndererek, çevrimiçi iletişimle, Eba deney videoları ile evde yapmalarını isteyerek tamamlayabileceklerini ifade etmişlerdir. Laboratuvar/ atölye çalışmalarını uzaktan eğitim ile tamamlayamayacağını düşünen Fen Bilimleri öğretmenleri ise bu çalışmaları öğrencilere; evde yapmalarını isteyerek telafi eğitimi vererek veya çeşitli videolar önererek kazandıracaklarını ifade etmişlerdir.

Araştırmanın dördüncü problemi olan Fen Bilimleri öğretmenlerinin COVID-19 pandemisi sürecinde öğretmenlik mesleği hakkındaki görüşlerine ilişkin bulgulara göre pandemi sürecinin mesleki hayatlarında eğitim teknolojileri kullanımını olumlu yönde etkilediği görülmektedir. $\mathrm{Bu}$ sonucu sürecin zorunlu kıldığı teknoloji kullanımının öğretmenlerin bu hususlarda kendilerini geliştirmeye mecbur bıraktığından kaynaklandığı söylenebilir. Alanyazında COVID-19 sürecinde öğretmenlerin uzaktan eğitim için birçok teknolojik donanımı ve yazılımı kullanmak durumda kaldığı rapor edilmektedir (Mulenga \& Marban, 2020; UNESCO, 2020). Bu konuyla ilgili olarak UNESCO (2020) öğretmenlere öğrencilerle uzaktan eğitimde hangi iletişim teknolojilerini kullanabileceklerine dair bir kılavuz da hazırlamıştır.

Araştırmaya katılan Fen Bilimleri öğretmenlerinin bu süreçte sınıf ortamında öğretmenlik yapamamanın büyük bir kısmında (\%58.6) kaygı oluşturduğu tespit edilmiştir. Kaygı nedenleri arasında ise öğrencide oluşabilecek bilgi eksikliği, mutsuzluk, uzaktan eğitimde kendini yetersiz hissetme ve öğrenciye ulaşamama gibi nedenlere bağlamışlardır. Yine pandemi sürecinin mesleki doyumlarını da olumsuz etkilediğini bunun başlıca sebebinin ise uzaktan eğitimde işe yaramama olduğunu ifade etmişlerdir. Salgın sırasında, öğretmen ve öğrenciler gibi çoğu insan evde kalmak zorunda kalmış, aile sağlı̆̆ 1 ve güvenliği, iş durumu ve aile geliri gibi hayatın diğer yönlerini irdelemek için daha fazla zamana sahip olmuşlarbudabireyleri daha fazla endişelenmeye yöneltmiştir (Wang ve diğerleri, 2020). Araştırmanın dördüncü problemi bağlamında katılımcılara COVID-19 pandemisinin mesleki gelişimlerini hangi yönde etkilediği sorulmuş ve büyük bir kısmının (\%84) mesleki gelişimlerine olumlu etkilediği ortaya çıkmıştır. Buna neden olarak; bu süreçte kendilerini geliştirme firsatı bulduklarını zor koşullarda bile ders verebildikleri için kendilerine güven duygusunun gelişmesine ve uzaktan eğitim sürecinde daha az yorulduklarına bağlamışlardır. Bu durum pandeminin öğretmenlere olumlu bir etkisi olarak karşımıza çıkmaktadır. Pandeminin araştırmaya katılan Fen Bilimleri öğretmenlerinin öğretmenlik mesleğine yönelik tutumlarında herhangi bir değişiklik meydana getirmediği tespit edilmiştir. Araştırmada ulaşılan birbaşka sonuç ise COVID-19 pandemisi sonrasında bazı Fen Bilimleri öğretmenleri sınıflarında çeşitli çalışmalar yapmayı planlamakta oldukları (29) tespit edilmiştir. Bu çalışmalar; konuların tekrar edilmesi, grup çalışmasının öneminin anlatılması, öğretim yöntemini değiştirme ve pandemiyi anlatma gibi sıralanabilmektedir.

\section{Öneriler}

Araştırmada ulaşılan sonuçların 1şığında gelecekte gerçekleştirilecek araştırmalara bazı tavsiyelerde bulunulmaktadır.

1.Bu araştırmanın katılımcılarını ortaokullarda görevli Fen Bilimleri öğretmen adayları oluşturmuştur. Diğer branşlardaki öğretmenlere yönelik de benzer araştırmaların gerçekleştirilmesi beklenmektedir. 
2.COVID-19 pandemisinin Türkiye'de eğitim sistemi politikalarına etkisinin incelenmesi önem arz etmektedir.

3.COVID-19 pandemisinineğitim sisteminin farklı paydaşlarına (Öğrenci, Öğretmen adayı, okul yöneticileri, öğretim programı, aile vb.) olan olumlu ya da olumsuz etkilerinin daha detaylı, boylamsal incelenmesi gerekmektedir.

4.Pandemi gibi dünya genelini etkileyen salgın, doğal afet gibi konuların öğretmenlereve öğrencilere kazandırılması için eğitimlerin verilmesi veya öğretim programlarına entegre edilmesi gerekmektedir.

5.Pandemi sırasında veya sonrasında öğretmenlerin bilişim teknolojileri kullanma ve uzaktan eğitim gerçekleştirme becerilerini geliştirmek adına çeşitli eğitimler düzenlenmelidir.

\section{Sinırlılıklar}

$\mathrm{Bu}$ araştırma Türkiye'de ortaokullarda görev yapan 75 Fen Bilimleri öğretmeni ile gerçekleştirilmiştir. Araştırma pandemi sürecine ilişkin Fen Bilimleri öğretmenlerinin görüşleri üzerine kurgulanmış nitel bir araştırmadır. Salgından ötürü görüşmeler dijital ortamda gerçekleştirilmiştir.

\section{Kaynakça}

Altıparmak, M. (2011). E-öğrenme ve uzaktan eğitimde açık kaynak kodlu öğrenme yönetim sistemleri. Malatya: Akademik Bilişim'11 - XIII. Akademik Bilişim Konferansı Bildirileri Kitabl, 319-327.

Angoletto, R.,\& Queiroz, V. C. (2020). COVID-19 and the challenges in education. The Centro de Estudos Sociedade e Tecnologia(CEST), 5, 2.

Baker, C.,Wuest, J., \& Stern, P.N. (1992). Methodslurring: thegroundedtheory/ phenomenologyexample. Journal of Advanced Nursing, 17, 1355-1360.

Baytiyeh, H. (2019). Why school resilience should be critical for the post-earthquakere covery of communities in divided societies. Education and Urban Society,51(5), 693-711.

Burke, J.,\& Dempsey, M. (2020). COVID-19 Practice in primaryschools in Ireland report. National University of Ireland Maynooth, Ireland. https://www.into.ie/app/uploads/2020/04/COVID-19-Practice-in-Primary-Schools-Report1.pdf.

Çetin, Ö., Çakıroğlu, M., Bayılmış, C., \& Ekiz, H. (2004). Teknolojik gelişme için eğitimin önemi ve internet destekli öğretimin eğitimdeki yeri. The Turkish Online Journal of Educational Technology, 3(3), 144-147.

Dünya Sağlık Örgütü [DSÖ] (2020). WHO director-general's opening remarks at the media briefing on COVID-19. https://www.who.int/dg/speeches/detail/who-director-general-sopening-remarks-at-the-media-briefing-on-COVID-19---11-march-2020.

Iwai, Y. (2020). Online Learning during the COVID-19 Pandemic: What do we gain and what do we lose when classrooms go virtual?', Scientific American. https://blogs.scientificamerican.com/observations/online-learning-during-the-COVID-19pandemic/.

Jasper, M. A. (1994). Issues in phenomenology for researchers of nursing. Journal of Advanced Nursing, 19, 309- 314. 
Kırık, A. M. (2014). Uzaktan eğitimin tarihsel gelişimi ve Türkiye'deki durumu. Marmara İletişim Dergisi,21, 73-94.

Lee, S. A. (2020). Coronavirus anxiety scale: A brief mental health screener for COVID-19 related anxiety. Death Studies. 44(7),1-9.http://dx.doi.org/10.1080/07481187.2020.1748481

Lin, C. Y. (2020). Social reaction toward the 2019 novel coronavirus (COVID-19). Social Health Behaviour, 3, 1-2.

Miks, J.,\&McIlwaine, J. (2020). Keeping the world's children learning through COVID-19. Research report, UNICEF. https://www.un_cef.org/coronav_rus/keep_ng-worlds-ch_ldrenlearn_ng-through-cov_d-19.

Miles, M, B.,\& Huberman, A. M. (1994). Qualitative data analysis: An expanded Sourcebook. (2nd ed). Thousand Oaks, CA: Sage.

Motiejūnaitè-Schulmeister, A.,\& Crosier, D. (2020). How is Covid-19 affecting schools in Europe? Research report. European Commission, EURYDICE. https://eacea.ec.europa.eu/nationalpolicies/eurydice/content/how-covid-19-affecting-schools-europe_

Mulenga, E. M.,\& Marbán, J. M. (2020). Is COVID-19 the gateway for digital learning in mathematics education? Contemporary Educational Technology, 12(2), ep269. https://doi.org/10.30935/cedtech/7949

Perienen, A. (2020). Frame works for ICT integration in mathematics education- a teacher's perspective. Eurasia Journal of Mathematics, Science and Technology Education, 16(6), em1845. https://doi.org/10.29333/ejmste/7803

Rovai, A. P.,\& Downey, J. R. (2010). Why some distance education programs fail while others succeed in a global environment. The Internet and Higher Education, 13(3), 141-147. http://dx.doi.org/10.1016/j.iheduc.2009.07.001

Roy, D. (2020). Trying to home school because of coronavirus? Here are 5 tips to help your childlearn. https://theconversation.com/trying-to-homeschool-because-of-coronavirus-hereare-5-tips-to-help-your-child-learn-133773.

Sintema, E. J. (2020). Effect of COVID-19 on the performance of grade 12 students: implications for STEM education. EURASIA Journal of Mathematics, Science and Technology Education, 16(7), 1-6.

Şen, B., Atasoy, F., \& Aydın, N. (2010). Düşük maliyetli web tabanlı uzaktan eğitim sistemi uygulamas1. XII. Akademik Bilişim Konferansı (ss 383-389). Muğla Üniversitesi.

Türkiye Bilimler Akademisi (TÜBA). (2020). COVID-19 pandemi değerlendirme raporu. http://www.tuba.gov.tr/tr/yayinlar/suresiz-yayinlar/raporlar/covid-19-pandemi degerlendirme-raporu.

Türk Dil Kurumu (TDK) (2020). Bilim ve sanat terimleri sözlüğ̈̈. 26 Nisan 2020 tarihinde https://sozluk.gov.tr/.

United Nations Educational, Scientific and Cultural Organization. [UNESCO], (2020). How to keep Engaged Remotely with Your Students in the Context of the COVID-19 Crisis: Tips for Teachers.https://en.unesco.org/news/resources-parents-and-teachers-motivating-supportingchildren-during-remote-learning.

Uzoğlu, M. (2017). Fen bilgisi öğretmen adaylarının uzaktan eğitime ilişkin görüşleri. Karadeniz Sosyal Bilimler Dergisi, 9(16), 335-351. 
Wang,Y.,Di, Y., Ye, J., \& Wei, W. (2020). Study on the public psychological states and its related factors during the outbreak of coronavirus disease 2019 (COVID-19) in some regions of China. Psychology, Health \& Medicine. http://dx.doi.org/10.1080/13548506.2020.1746817

Yıldırım, A., \&Şimşek, H. (2013). Sosyal bilimlerde nitel araştırma yöntemleri. (5. Bask1). SeçkinYayınları. 